\title{
KERAGAMAN SIFAT KUALITATIF DAN MORFOMETRIK ANTARA AYAM KAMPUNG, AYAM BANGKOK, AYAM KATAI, AYAM BIRMA, AYAM BAGON DAN MAGON DI MEDAN
}

\author{
(Diversity of Qualitative Trait and Morphometrics Between Kampung, Bangkok, Katai, \\ Birma, Bagon and Magon Chicken in Medan) \\ Eka N Sitanggang ${ }^{1}$, Hasnudi $^{2}$, dan Hamdan ${ }^{3}$ \\ 1. Mahasiswa Program Studi Peternakan Fakultas Pertanian Universitas Sumatera Utara \\ 2. Staf Pengajar Program Studi Peternakan Fakultas Pertanian Universitas Sumatera Utara
}

\begin{abstract}
The objective of the research to find out the diversity of phenotype with genotype and Morphometrics Between Kampung, Bangkok, Katai, Birma, Bagon and Magon Chicken. The research conducted in nine different locations in six subdistrict of Medan using 368 chicken. Data collection was done by observations on the qualitative include feather color, feather pattern, feather feature, feather shine, shank color and comb shape and morphometric of body. The data obtained were analyzed simple discriminant analysis using the SAS program (Statistical Analysis System) and Dendogram using the program MEGA (Molecular Evolutionary Genetic Analysis). The results of freedom test showed that highly significant relationship $\left(X^{2}>X_{0,05}^{2}\right)$ between feather pattern, feather feature, feather shine, shank color and comb shape, but non-significant $\left(X^{2}<X_{0,05}^{2}\right)$ between feather color and also type of chicken. The phenotypically purity of Katai chicken 100\%, Kampung 98,46\%, Bangkok 84,13\%, Bagon 75,00\%, Magon 65,00\% dan Birma 40,00\%. Variable differential factor for body morphometrics was femur length, tibia length, shank length, shank ring, wing length, maxilla length and finger third length. Bagon and Magon has a close genetic distance, while the Kampung dan Katai has a far genetic distance.
\end{abstract}

Keywords : Chicken, qualitative trait, phenotype, genotype, morphometrics

\begin{abstract}
ABSTRAK
Penelitian ini bertujuan mengetahui keragaman fenotipe serta genotipe dan morfometrik antar ayam Kampung, ayam Bangkok dan ayam Katai, ayam Birma, Bagon dan Magon. Penelitian ini dilakukan di Sembilan lokasi berbeda di enam Kecamatan Kota Medan menggunakan 368 ekor ayam. Pengambilan data dilakukan dengan cara pengamatan pada sifat kualitatif meliputi warna bulu, pola bulu, corak bulu, kerlip bulu, warna shank dan bentuk jengger dan morfometrik tubuh. Data yang diperoleh diolah dengan analisis diskriminan sederhana dengan menggunakan program SAS (Statistical Analysis System) dan Dendogram menggunakan program MEGA (Molekuler Evolusioner Genetic Analysis). Hasil penelitian uji kebebasan menunjukkan bahwa adanya keterhubungan yang sangat nyata $\left(X^{2}>X_{0,05}^{2}\right)$ antara sifat pola bulu, corak bulu, kerlip bulu, warna shank dan bentuk jengger, tetapi tidak adanya keterhubungan $\left(X^{2}<X_{0,05}^{2}\right)$ antara warna bulu dan jenis ayam yang diamati. Kemurnian fenotifik masing-masing jenis ayam ialah jenis Katai 100\%, Kampung 98,46\%, Bangkok 84,13\%, Bagon 75,00\%, Magon 65,00\% dan Birma 40,00\%. Faktor peubah pembeda morfologi tubuh dari keenam jenis ayam ialah panjang femur, panjang tibia, panjang shank, lingkar shank, panjang sayap, panjang maxilla dan panjang jari ketiga. Jarak genetik ayam Bagon dengan ayam Magon memiliki jarak genetik yang dekat, sebaliknya ayam Kampung dan ayam Katai memiliki jarak genetik yang jauh.
\end{abstract}

Kata kunci: Ayam, sifat kualitatif, fenotipe, genotipe, morfometrik 


\section{PENDAHULUAN}

Ayam adalah binatang yang termasuk bangsa gallus. Ayam merupakan salah satu sumber daya genetik lokal di Indonesia, salah satu contohnya adalah ayam lokal, baik yang asli Indonesia maupun yang berasal dari luar negeri yang telah beradaptasi di Indonesia selama beberapa generasi. Ayam lokal lebih mudah dipelihara dan lebih tahan terhadap penyakit jika dibandingkan dengan ayam yang berasal dari luar negeri. Sebagian besar ayam lokal yang berasal dari Indonesia dipelihara secara ekstensif dengan sistem tradisional sehingga ayam-ayam tersebut bebas berkeliaran mencari makanan dan tidur dimanapun mereka suka seperti di pohon dan disetiap pinggir rumah masyarakat penduduk.

Ayam Kampung, ayam Bangkok dan ayam Katai dimasukkan ke dalam rumpun ayam lokal Indonesia. Ayam Birma, ayam Magon (Birma x Shaigon) dan Bagon (Bangkok x Shaigon) merupakan variatif ayam baru yang kepopulerannya belum begitu menonjol perkembangannya di Indonesia (Syahrul, 2013). Ayam Kampung merupakan salah satu sumber protein hewani yang penting di Indonesia terutama umat muslim (Nishida et al., 1980). Ayam Bangkok adalah hasil persilangan antara ayam Melayu dengan ayam lokal di daerah Ayutthaya, Bangkok Utara, yang ternyata berhasil dikembangkan sebagai bibit unggul, baik sebagai ayam petelur dan pedaging maupun sebagai ayam aduan. Sedangkan Ayam Katai merupakan jenis ayam buras (bukan ras) dengan karakteristik yang unik termasuk jenis ayam yang sangat kecil dan berkaki pendek, akan tetapi pial dan jengger kepalanya besar. Ayam Katai bukan asli ayam lokal yang berasal dari Indonesia, akan tetapi telah telah mengalami beberapa persilangan di Indonesia sehingga jenis dari ayam ini sangat beragam.

Masih sedikit informasi yang bisa kita dapatkan mengenai sumberdaya genetik ayam buras (bukan ras), terutama ayam lokal Indonesia. Informasi ini sangat penting bagi pengembangkan ternak ayam ke depannya. Oleh karena itu diperlukan penelitian dasar mengenai karakteristik fenotipe baik sifat kualitatif maupun kuantitatif dari setiap tipe ayam lokal pada daerah spesifik Sumatera Utara. Keragaman sifat kualitatif dan morfometrik anatar ayam Kampung, Bangkok, katai, Birma, Magon dan Bagon adalah untuk memperoleh data dasar tentang fenotipe dan genotipe keenam jenis ayam tersebut.

Pengembangan ayam secara umum harus disertai dengan perbaikan manajemen pemeliharaan dan peningkatan mutu genetik. Peningkatan mutu genetik ayam baik sebagai 
penghasil daging atau penghasil telur serta hewan piaraan perlu dilakukan agar diperoleh ayamayam yang unggul. Peningkatan mutu genetik dapat dilakukan dengan pemuliaan yaitu seleksi atau persilangan. Kebijakan pemuliaan yang diambil harus sesuai dengan keadaan ayam saat ini. Oleh sebab itu, diperlukan berbagai informasi mengenai karakteristik dan keragaman fenotipe ayam lokal di Indonesia. Studi keragaman fenotipe dapat dilakukan untuk mengetahui keragaman genetik ayam. Penelitian-penelitian dasar mengenai keragaman dan karakteristik morfologi perlu dilakukan agar diperoleh data yang valid sehingga kebijakan pemuliaan dapat dilakukan.

Didalam upaya mempertahankan, menggali dan mengembangkan potensi sumberdaya masing-masing ayam lokal, langkah awal yang perlu dilakukan antara lain dengan menghimpun informasi dan karakterisasi yang berkaitan dengan sejumlah sifat ekonomis penting seperti bobot badan dan ukuran-ukuran tubuh. Data awal sifat ekonomis penting ayam tersebut berguna bagi penentuan kebijakan selanjutnya dalam kegiatan pemuliaan dan budidaya ayam lokal sehingga mampu menjadi sumber pangan hewani yang potensial bagi masyarakat Indonesia.

Ayam lokal yang terdapat di Indonesia sangat beragam penampilannya, dan penyebarannya cukup luas di kota maupun di desa. Hal ini menunjukkan bahwa ayam lokal punya potensi sangat baik untuk dikembangkan, namun kenyataannya potensi itu belum dimanfaatkan secara optimal. Hal itu terlihat dari lambannya populasi ayam lokal yang dipelihara masyarakat dari tahun ke tahun, dan sedikitnya jumlah pemilik ayam tersebut pada setiap rumah tangga.

\section{BAHAN DAN METODE PENELITIAN}

\section{Lokasi dan Waktu Penelitian}

Penelitian dilaksanakan di Sembilan tempat yaitu JL. Martubung di Kecamatan Medan Labuhan untuk pengamatan ayam Bangkok, ayam Birma, ayam Bagon (Bangkok x Saigon) dan Magon (Birma x Saigon), JL. Sukadono di Kecamatan Medan Helvetia, JL. Perwira Utama di kecamatan Medan Sunggal, JL. Keluarga di Kecamatan Medan Selayang dan JL. Simpang Melati di Kecamatan Medan Tuntungan untuk pengamatan ayam Kampung, serta JL. Amir Hamzah di kecamatan Medan Sunggal, JL. Bintang di Kecamatan Medan Kota, JL. Amal di Kecamatan Medan Sunggal dan JL Sakura di Kecamatan Medan Selayang untuk pengamatan ayam Katai. Penelitian ini dilaksanakan pada November 2013 hingga Maret 2014. 


\section{Bahan dan Alat}

Bahan yang digunakan dalam penelitian ini adalah 368 ekor ayam, terdiri dari 130 ekor ayam Kampung (48 ekor jantan dan 82 ekor betina), 126 ekor ayam Bangkok (106 ekor jantan dan 20 ekor betina) , 20 ekor ayam Birma jantan, 20 ekor ayam Magon (Birma x Shaigon) jantan, 20 ekor ayam Bagon (Bangkok x Shaigon) dan 52 ekor ayam Katai (30 ekor jantan dan 22 ekor betina). Umur ayam yang digunakan dalam penelitian ini bervariasi, diperkirakan telah mencapai dewasa kelamin dan berkisar pada umur 1-2 tahun.

Alat yang digunakan selama penelitian ini terdiri atas jangka sorong digital yang memiliki skala minimum $0 \mathrm{~mm}$ dan maksimum 153,09 $\mathrm{mm}$ dan jangka sorong dengan skala nonius 0,05 mm dengan batasan ukur $15 \mathrm{~cm}$, pita ukur dengan merk Butterfly Brand yang memiliki skala minimum $1 \mathrm{~mm}$ dan maksimum $150 \mathrm{~mm}$, lembar data dan alat tulis untuk mencatat hasil pengamatan ukuran-ukuran tubuh, kamera digital untuk pengambilan dokumentasi dan perangkat lunak Statistical Analysis System (SAS) dan Molekuler Evolusioner Genetic Analysis (MEGA) digunakan untuk menganalisis data.

\section{Metode Penelitian}

Metode penelitian yang digunakan adalah metode deskriktif. Data diperoleh dengan melakukan pengamatan langsung terhadap sifat kualitatif serta pengukuran Setiap organ tubuh bagian luar terhadap sampel.

\section{Parameter Penelitian}

1. Sifat-sifat kualitatif warna bulu, pola bulu, corak bulu, kerlip bulu, warna shank dan bentuk jengger.

2. Morfometrik bagian tubuh luar.

Sifat yang dapat dibedakan atau dikelompokkan, seperti warna bulu, warna shank dan bentuk jengger pada ayam disebut sebagai sifat kualitatif. Ekspresi sifat kualitatif ditentukan oleh satu gen tunggal sampai dua pasang gen. Perbedaan sifat ini hampir seluruhnya ditentukan oleh perbedaan genetik, sedangkan perbedaan lingkungan memberikan pengaruh yang kecil bahkan tidak ada, sehingga variasi sifat kualitatif juga merupakan variasi genetik (Warwick at al. 1995).

Pengukuran ukuran linear permukaan tubuh ternak sebagai sifat kuantitatif dapat digunakan dalam seleksi, Dijelaskan lebih lanjut bahwa pengukuran linear tubuh tersebut 
dilakukan untuk memperoleh perbedaan-perbedaan ukuran-ukuran tubuh dalam populasi ternak (Mulliono, 1996).

\section{Pengamatan Genetik}

Data kualitatif yang diamati meliputi warna bulu, pola bulu, corak bulu, kerlip bulu, warna shank dan bentuk jengger

\section{Warna Bulu}

Individu dengan warna dasar hitam polos digolongkan pada fenotipe polos yang membawa gen berwarna (i) dan gen (E). Individu dengan bulu seperti garis-garis memanjang dipunggung digolongkan pada fenotipe warna bulu tipe liar, yang membawa gen pola warna bulu tipe liar (e+). Individu dengan bagian ujung ekor dan ujung sayap berwarna hitam digolongkan pada fenotipe warna bulu pola kolombian, membawa gen pola warna bulu kolombian (e) (Mansjoer et al. 1989).

\section{Bentuk Jengger}

Individu dengan jengger ros digolongkan pada fenotipe bentuk jengger ros (R_pp), individu dengan jengger kapri digolongkan pada fenotipe bentuk jengger kapri (rrP_) dan individu dengan jengger tunggal digolongkan pada fenotipe bentuk jengger tunggal (rrPP) (Nishida, 1982).

\section{Warna Shank}

Individu dengan cakar berwarna putih/kuning digolongkan pada fenotipe warna shank berwarna putih/kuning (Id_) dan individu dengan shank berwarna hitam digolongkan pada fenotipe warna hitam/abu-abu (idid_) (Somes 1988).

\section{Pengamatan Fenotipik}

Data morfometrik yang diamati meliputi bagian-bagian tubuh yang diukur yaitu panjang femur, panjang Tibia, Panjang Tarsometatarsus/shank, Lingkar Shank, Panjang Sayap, Panjang Maxilla, Pajang Jari Ketiga dan panjang jengger. Adapun cara pengukuran yang dilakukan adalah:

\section{Panjang Femur}

Tulang femur memiliki bentuk yang agak melengkung, kuat dan silindrikal. Bagian ujung distal berartikulasi dengan tibia, fibula dan patellan. Pengukuran panjang tulang femur dilakukan sepanjang tulang paha dengan menggunakan jangka sorong. 


\section{Panjang Tibia}

Bagian lateral tibia berikatan dengan fibula dan bagian proximal berikatan dengan tulang femur). Pengukuran tulang tibia ini dilakukan dari patella sampai ujung tibia dengan menggunakan jangka sorong.

\section{Panjang Tarsometatarsus atau Shank}

Panjang tulang tarsometatarsus diwakili oleh sebuah tulang yang dibentuk oleh persatuan metatarsal yang kedua, ketiga dan keempat Pengukuran dilakukan sepanjang tulang tarsometatarsus (shank) dengan menggunakan jangka sorong.

\section{Lingkar Shank}

Pengukuran lingkar tarsometatarsus (shank) dilakukan dengan melingkarkan pita ukur pada bagian tengah tulang tarsometatarsus dan kemudian dikonversikan ke jangka sorong.

\section{Panjang Sayap}

Tulang sayap terdiri dari tulang humerus, radius dan ulna. Pengukuran dilakukan mengikuti tulang-tulang penyusun tulang sayap mulai dari pangkal humerus sampai ujung phalanges menggunakan pita ukur yang kemudian dikonversikan ke jangka sorong.

\section{Panjang maxilla}

Panjang maxilla diukur dari bagian pangkal rahang atas bagian luar sampai ke ujung bawah paru dengan menggunakan jangka sorong.

\section{Panjang Jari ketiga}

Pengukuran hanya dilakukan pada jari terpanjang yang terdiri dari empat phalanges sampai ujung jari menggunakan jangka sorong.

\section{Tinggi Jengger}

Pengukuran dilakukan dari bagian pangkal bawah jengger yang melekat pada atas maxilla sampai pangkal atas jengger menggunakan jangka sorong. Pengukuran ukuran-ukuran tubuh ayam dilakukan berdasarkan sistem kerangka (skeletal system) (Jull, 1951).

\section{Analisis Data}

\section{Frekuensi Fenotipe Sifat Kualitatif}

Data sifat kualitatif yang berupa warna bulu, warna shank dan bentuk jengger dianalisis secara deskriktif berdasarkan frekuensi fenotipenya. Frekuensi fenotipe warna bulu, warna shank 
dan bentuk jengger dihitung berdasarkan jumlah fenotipe yang muncul dibagikan jumlah seluruh individu yang diamati dikali $100 \%$. Dengan formula sebagai berikut:

$$
\text { Frekuensi Fenotipe } \mathrm{A}=\frac{\text { Jumlah ternak sifat } \mathrm{A}}{\mathrm{n}} \times 100 \%
$$

Keterangan : $\mathrm{A}=$ Jumlah fenotipe $\quad \mathrm{n}=$ total sampel ayam yang diamati

Data yang telah diperoleh dianalisis dengan uji kebebasan $\left(X^{2}\right)$ untuk mengetahui hubungan antara warna bulu, warna shank (cakar) dan tipe jengger dari ayam yang diamati. Rumus Uji Kebebasan menurut Walpole (1995) sebagai berikut:

$$
e=\underline{\text { (Total Kolom }) \times(\text { Total Baris) }}
$$

Total Pengamatan

$$
X_{h i t}^{2}=\sum(\underline{o-e})^{2}
$$

$e$

Keterangan: $\quad X_{h i t}^{2}=$ Nilai chi-kuadrat

$o=$ Frekuensi observatif (Pengamatan)

$e=$ Frekuensi ekspektasi (harapan)

Bila $X_{h i t}^{2}>X_{\alpha}^{2}$ dengan derajat bebas sebesar (r-1) (c-1), maka hipotesis nol (H0) ditolak. Kedua kelompok itu tidak bebas atau tergantung/ berhubungan pada taraf nyata $\alpha(0,05)$, selain dari itu maka H0 diterima.

\section{Frekuensi Gen}

Untuk menganalisis gen yang mengontrol karakteristik morfologi sifat kualitatif dihitung berdasarkan frekuensi gen autosomal dan sex-linked (gen terpaut kelamin). Frekuensi gen autosomal dominan dihitung dengan rumus:

$$
\begin{aligned}
& \mathrm{q}=1-\sqrt{\mathrm{R} / \mathrm{N}} \\
& \mathrm{p}=1-\mathrm{q}
\end{aligned}
$$

Keterangan:

$\mathrm{q}=$ frekuensi gen dominan otosomal

$\mathrm{R}=$ jumlah individu dengan ekspresi resesif (homozigot resesif)

$\mathrm{N}=$ jumlah total individu yang diamati

$\mathrm{p}=$ frekuensi gen resesif autosomal

Frekuensi frekuensi gen dominan resesif pada alel ganda yang terletak pada autosom menggunakan hukum Hardy-Weinberg, dengan rumus Stanfield (1983) sebagai berikut:

$$
r=\sqrt{ } r^{2}
$$




$$
\begin{aligned}
& q=\sqrt{ }\left(q+r^{2}\right)-r \\
& p=1-q-r
\end{aligned}
$$

Keterangan:

$p=$ frekuensi gen $E(I)$

$$
\mathrm{q}=\text { frekuensi gen } \mathrm{e}^{+} \text {(II) }
$$$$
r=\text { frekuensi gen e (III) }
$$

Frekuensi gen sex-linked dominan dapat dihitung dengan menggunakan rumus menurut Nishida et al. (1980):

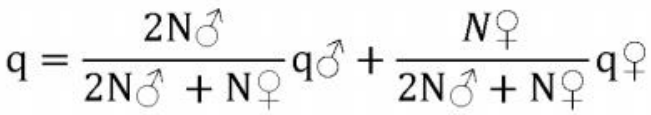

$$
\begin{aligned}
& \mathrm{q}^{*}=1-\sqrt{\mathrm{R} / \mathrm{N}} \quad \text { dan } \quad \mathrm{q}+=\underline{\mathrm{N}}+\mathrm{R} \text { 的 } \\
& \mathrm{N} \text { ㅇ }
\end{aligned}
$$

Frekuensi gen yang bersifat resesif: $\mathrm{p}=1-\mathrm{q}$

Keterangan:

$\mathrm{q}=$ frekuensi gen dominan

$\mathrm{p}=$ frekuensi gen resesif

$\mathrm{R}=$ jumlah individu dengan ekspresi resesif

$\mathrm{N}=$ jumlah total individu yang diamati

$\mathrm{q}^{*}=$ frekuensi gen dominan pada kelompok jantan

$\mathrm{q}+$ = frekuensi gen dominan pada kelompok betina

No $=$ jumlah individu jantan

$\mathrm{N}$ $=$ jumlah individu betina

\section{Analisis Morfometrik}

Aralisis statistik deskriptif ditunjukkan untuk memperoleh karakterisasi ukuran-ukuran tubuh pada ayam. Analisis ini dilakukan dengan menghitung nilai rataan $(\mathrm{X})$, simpangan baku (s) dan koefisien keragaman (KK) dengan prosedur statistik berikut:

$$
\bar{X}=\underline{\sum_{i-1}^{n} X i} \quad s=\sqrt{\frac{\sum_{n-1}^{n}(X i-\bar{X})^{2}}{\cdots}} \quad \mathrm{KK}=\stackrel{s}{=}(100 \%)
$$

Keterangan :

$X \quad$ : rata-rata

S : simpangan baku

$\mathrm{Xi} \quad$ : ukuran ke-i dari peubah $\mathrm{x}$

$\mathrm{n} \quad$ : jumlah sampel yang diambil dari populasi 
KK : koefisien keragaman

Untuk membandingkan kelompok antar jenis ayam dilakukan uji-t dengan menggunakan rumus sebagai berikut :

$$
\mathrm{t}_{\mathrm{h}}=\frac{\bar{x}_{1}-\bar{x}_{2}}{\sqrt{\frac{\sum\left(\mathrm{x}_{1 \mathrm{j}}-\mathrm{x}_{1}\right)^{2}}{n_{1\left(\mathrm{n}_{1}-1\right)}}+\frac{\sum\left(\mathrm{x}_{2 \mathrm{j}}-\mathrm{x}_{21}\right)^{2}}{n_{2\left(\mathrm{n}_{2}-1\right)}}}}
$$

Keterangan:

$$
\begin{array}{ll}
\mathrm{t}_{\mathrm{h}} & =\text { nilai } \mathrm{t} \text { hitung } \\
\mathrm{X}_{1} & =\text { rataan sampel pada kelompok ke-1 } \\
\mathrm{X}_{2} & =\text { rataan sampel pada kelompok ke-2 } \\
\mathrm{X}_{\mathrm{ij}} & =\text { nilai pengamatan ke-j pada kelompok pertama } \\
\mathrm{X}_{2 \mathrm{j}} & =\text { nilai pengamatan ke-j pada kelompok kedua } \\
\mathrm{n}_{1}, \mathrm{n}_{2} & =\text { jumlah sampel pada kelompok ke- } 1 \text { dan ke-2 }
\end{array}
$$

\section{Keragaman Genetik}

Jarak genetik ditentukan dengan menggunakan fungsi diskriminan sederhana (D ${ }^{2}$. Analisis diskriminan dilakukan menggunakan peubah panjang femur, panjang tibia, panjang shank, lingkar shank, panjang sayap, panjang maxilla, panjang jari ketiga dan panjang jengger.

Fungsi diskriminan yang digunakan adalah melalui pendekatan jarak Mahalonobis dengan menggabungkan matriks peragam antara peubah dari masing-masing ayam yang diamati menjadi sebuah matriks. Statistik D ${ }^{2}$-Mahalanobis dihitung dengan rumus sebagai berikut:

$$
\mathrm{D}_{(\mathrm{i}, \mathrm{j})}^{2}=\left(X_{i}-X_{j}\right) C^{-1}\left(X_{i}-X_{j}\right)
$$

Keterangan:

$D_{(i, j)}^{2}$ : Nilai statistik Mahalanobis sebagai ukuran jarak kuadrat genetik antar kelompok ayam ke-i dan kelompok ayam ke-j;

$C^{-1}:$ Kebalikan matrik gabungan ragam peragam antar peubah;

$X_{I}$ : Vektor nilai rataan pengamatan dari kelompok ayam ke-i pada masing-masing peubah kuantitatif; dan

$X_{j} \quad$ : Vektor nilai rataan pengamatan dari kelompok ayam ke-j pada masing-masing peubah kuantitatif. 
Setelah perhitungan jarak kuadrat, kemudian dilakukan pengakaran terhadap hasil kuadrat jarak, agar jarak genetik yang didapat bukan dalam bentuk kuadrat. Hasil pengakaran dianalisis lebih lanjut dengan program MEGA untuk memperoleh pohon fenogram, dengan asumsi bahwa laju evolusi antar kelompok ayam adalah sama.. Analisis statistik Mahalanobis dikerjakan menggunakan paket program SAS dengan prosedur PROC CANDISC dan PROC DISCRIM.

Penentuan penyebaran ayam dan nilai kesamaan diantara jenis ayam digunakan analisis kanonikal. Analisis ini juga digunakan dalam menentukan beberapa peubah ukuran fenotipik yang memiliki pengaruh kuat terhadap penyebab terjadinya pengelompokkan antara jenis ayam. Prosedur analisisnya menggunakan PROC CANDISC dari SAS.

\section{HASIL DAN PEMBAHASAN}

\section{Frekuensi Fenotipe Kualitatif}

\section{Warna Bulu}

Berdasarkan hasil penelitian warna bulu pada ayam Bagon, Bangkok, Birma, Kampung, Katai dan Magon disajikan pada tabel 1. Pengamatan yang dilakukan menunjukkan hasil uji kebebasan bahwa tidak adanya keterhubungan $\left(X^{2}<X_{0,05}^{2}\right)$ antara sifat warna bulu dengan keenam jenis ayam yang diamati. Tipe bulu berwarna terbanyak dijumpai pada ayam Bagon dan Magon dengan frekuensi masing-masing $100 \%$.

Frekuensi bulu putih paling banyak ditemukan pada ayam Katai dengan persentase tertinggi sebesar 5,77\%, namun frekuensi bulu putih tidak ditemukan pada ayam Bagon dan Magon dikarenakan hampir seluruh bulu di tubuh kedua jenis ayam yang ditemukan memiliki bulu berwarna. Hal ini sesuai dengan pernyataan North dan Bell (1990) yang menyatakan keragaman warna bulu pada banyak situasi bergantung pada letak bulu ditubuh ayam. Namun kemunculan warna bulu putih ada juga yang disebabkan oleh tidak adanya pigmentasi pada bulu dan memang tidak ada gen warna atau yang biasa disebut albino dan sifat bulu putih ini bersifat resesif pada gen bulu warna. 

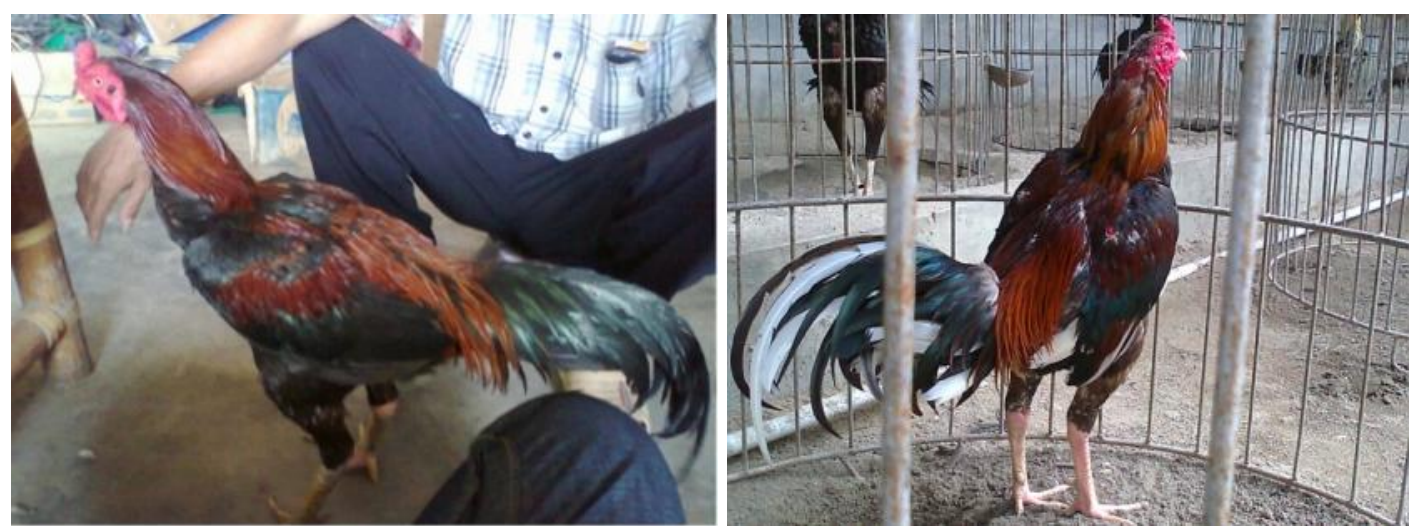

Keterangan 1: Variasi warna dan pola bulu ayam Bagon (Bangkok x Saigon)
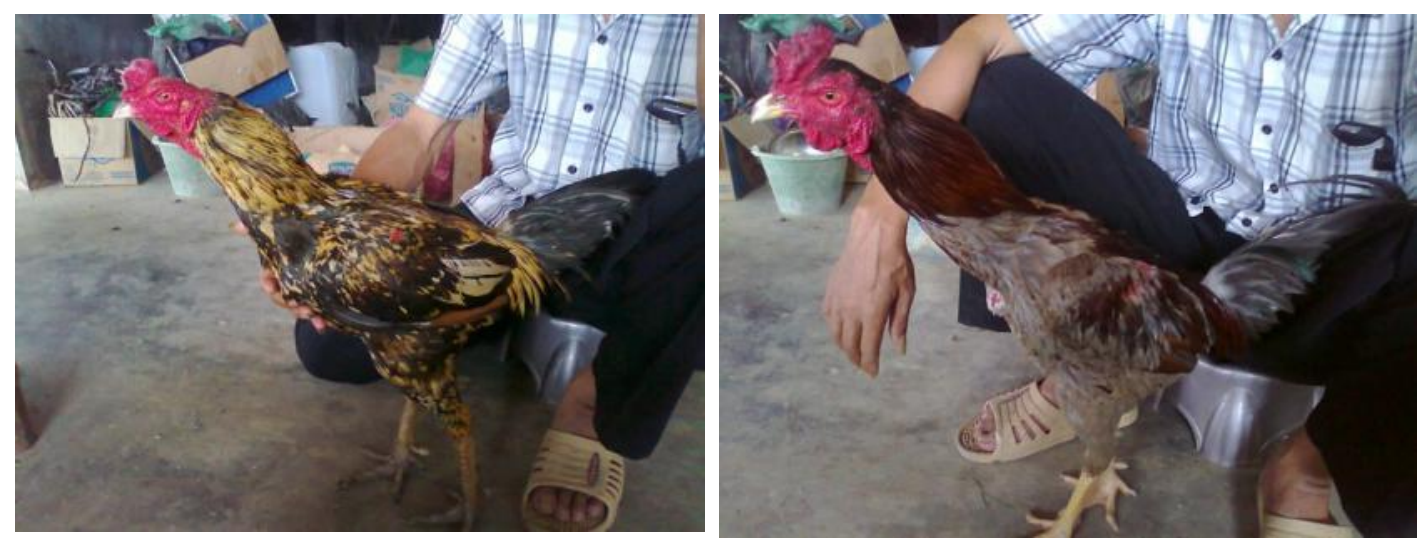

Keterangan 2: Variasi warna dan pola bulu ayam Magon (Birma x Saigon)
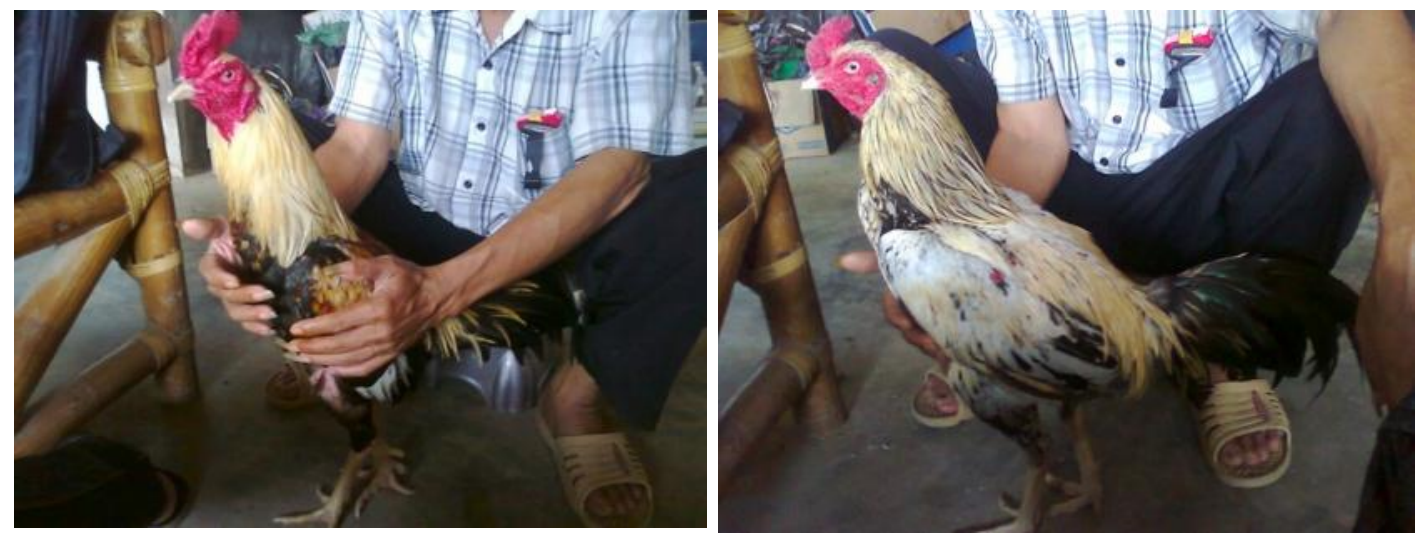

Keterangan 3: Variasi warna dan pola bulu ayam Birma 

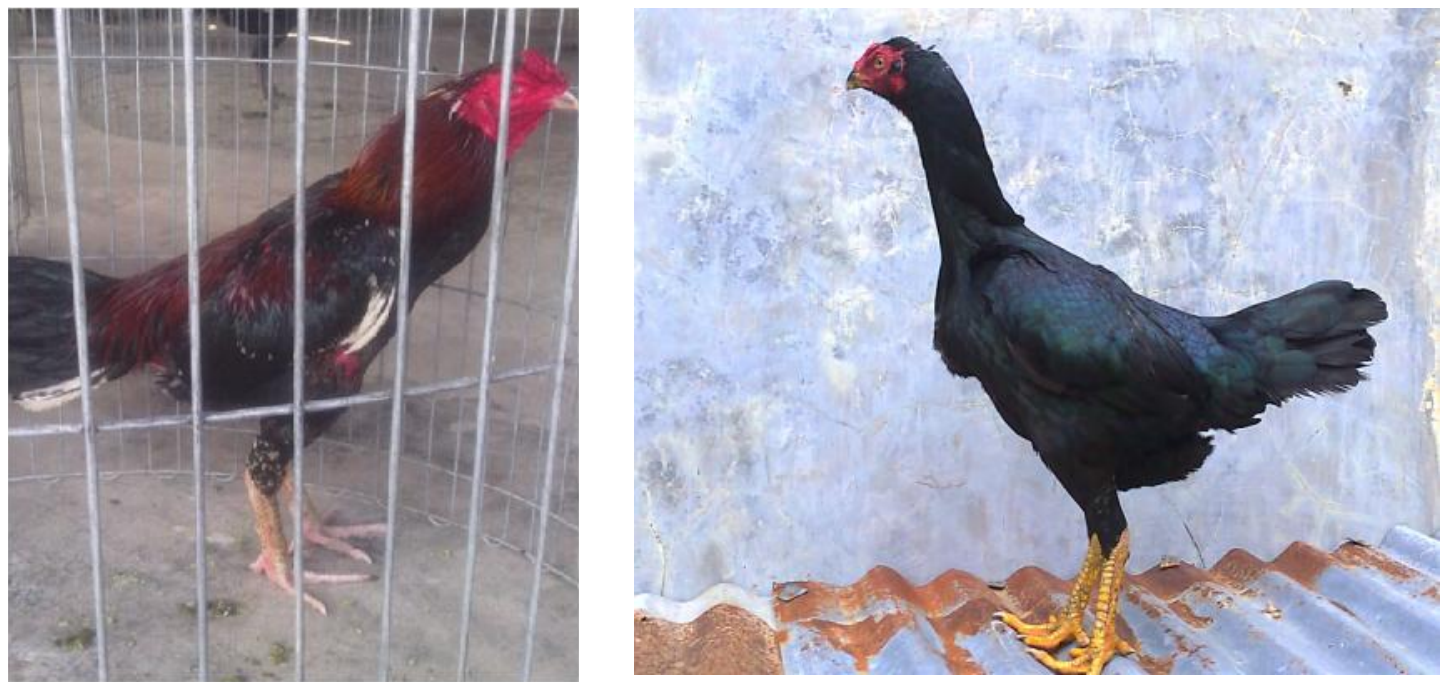

Keterangan 4: Variasi warna dan pola bulu ayam Bangkok
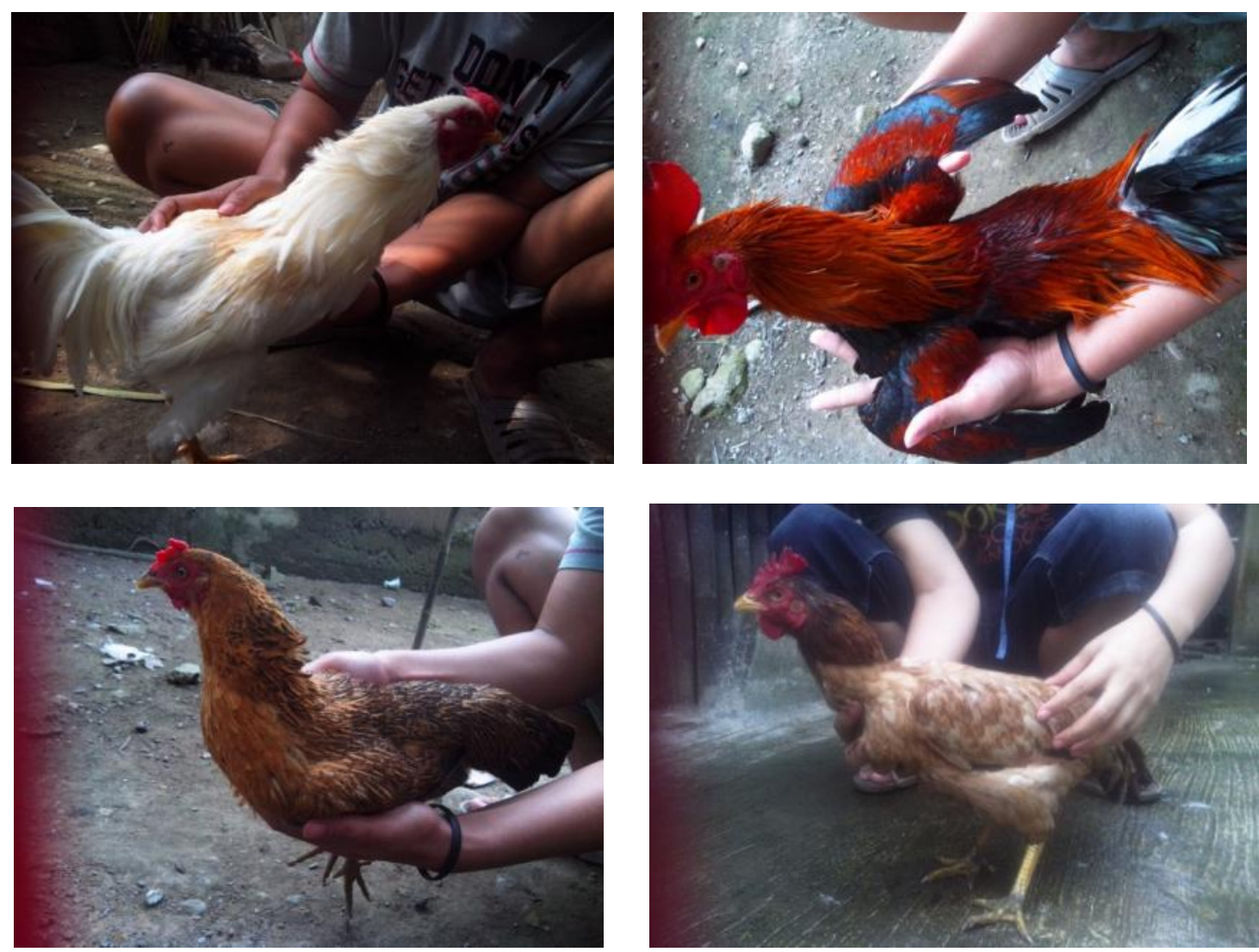

Keterangan 5: Variasi warna dan pola bulu ayam Kampung 

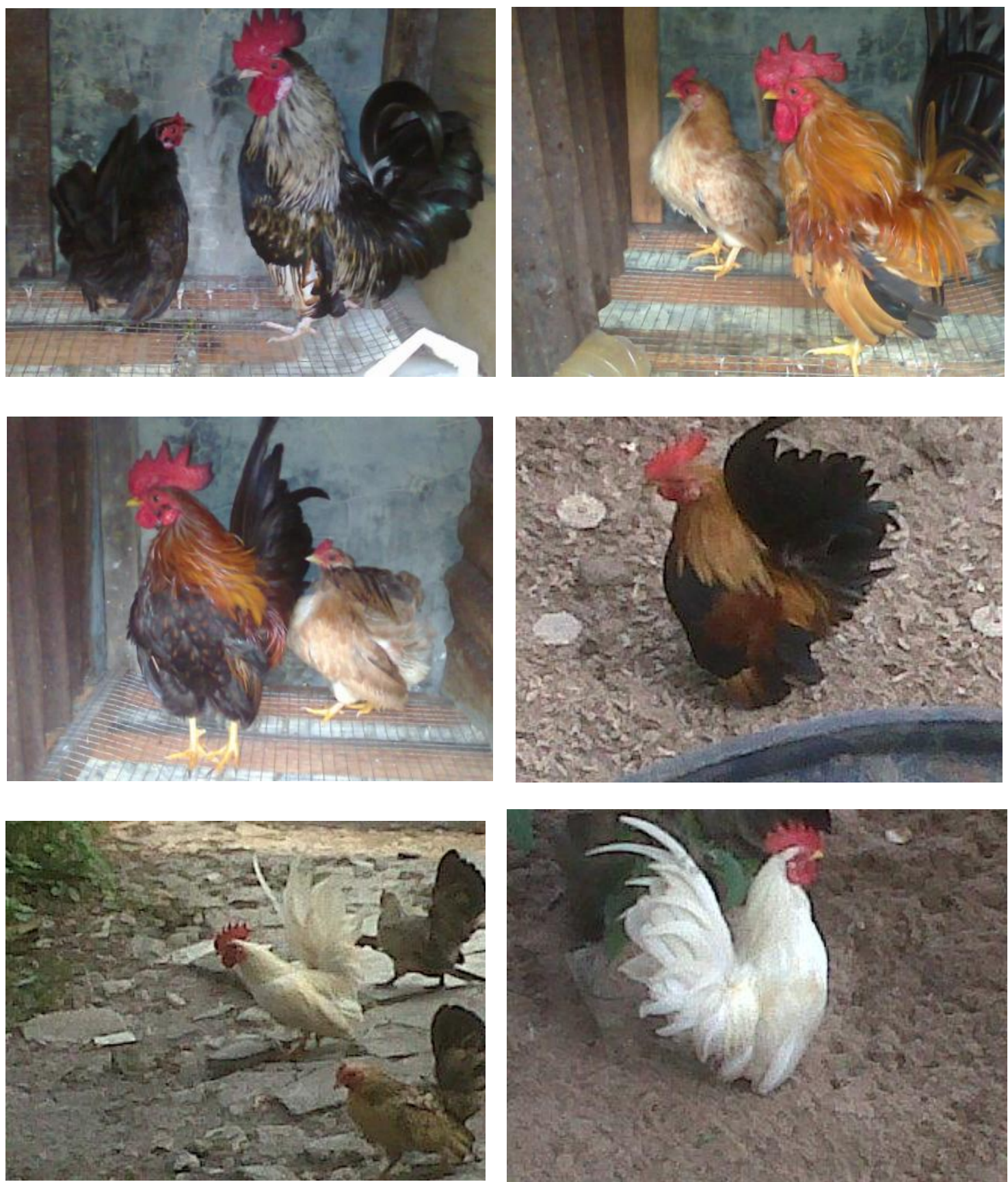

Keterangan 6: Tampilan gambar diatas menunjukkan ayam katai (kate) didominasi oleh pola bulu tipe liar

Gambar 1. Variasi warna bulu dan pola bulu antar jenis ayam yang diamati

\section{Pola Bulu}

Pola warna pada ayam adalah warna hitam, tipe liar dan Columbian. Berdasarkan hasil penelitian pola bulu pada ayam Bagon, Bangkok, Birma, Kampung, Katai dan Magon disajikan pada tabel diatas. Hasil uji kebebasan menunjukkan bahwa adanya keterhubungan $\left(X^{2}>X^{2}{ }_{0,05}\right)$ 
antara sifat pola bulu dengan keenam jenis ayam yang diamati. Pola warna bulu hitam banyak dijumpai pada ayam Kampung (51,54\%), tipe liar banyak dijumpai pada ayam Katai $(94,23 \%)$ dan pola warna Columbian banyak dijumpai pada ayam Bagon (50\%).

Tabel 1. Frekuensi fenotipe sifat kualitatif bulu ayam bagon, bangkok, birma, kampung, katai dan magon

\begin{tabular}{|c|c|c|c|c|c|c|c|c|c|c|c|c|}
\hline \multirow{3}{*}{ Sifat Kualitatif } & \multicolumn{12}{|c|}{ Frekuensi Fenotipe Pada Jenis Ayam } \\
\hline & \multicolumn{2}{|c|}{$\begin{array}{l}\text { Bagon } \\
(n=20)\end{array}$} & \multicolumn{2}{|c|}{$\begin{array}{l}\text { Bangkok } \\
(\mathrm{n}=126) \\
\end{array}$} & \multicolumn{2}{|c|}{$\begin{array}{c}\text { Birma } \\
(n=20)\end{array}$} & \multicolumn{2}{|c|}{$\begin{array}{l}\text { Kampung } \\
(\mathrm{n}=130)\end{array}$} & \multicolumn{2}{|c|}{$\begin{array}{l}\text { Katai } \\
(n=52)\end{array}$} & \multicolumn{2}{|c|}{$\begin{array}{l}\text { Magon } \\
(n=20)\end{array}$} \\
\hline & $\mathrm{n}$ & $(\%)$ & $\mathrm{n}$ & $(\%)$ & $\mathrm{n}$ & $(\%)$ & $\mathrm{n}$ & $(\%)$ & & $(\%)$ & $\mathrm{n}$ & $(\%)$ \\
\hline $\begin{array}{l}\text { Warna Bulu } \\
\text { Putih (I-) }\end{array}$ & 0 & 0,00 & 2 & 1,59 & 1 & 5,00 & 2 & 1,54 & 3 & 5,77 & 0 & 0,00 \\
\hline $\begin{array}{l}\text { Berwarna (ii) } \\
\text { Pola Bulu }\end{array}$ & 20 & 100,00 & 124 & 98,41 & 19 & 95,00 & 128 & 98,46 & 49 & 94,23 & 20 & 100,00 \\
\hline Hitam (E-) & 5 & 25,00 & 40 & 31,74 & 1 & 5,00 & 67 & 51,54 & 3 & 5,77 & 4 & 20,00 \\
\hline Tipe Liar (e+) & 5 & 25,00 & 43 & 34,13 & 17 & 85,00 & 38 & 29,23 & 49 & 94,23 & 11 & 55,00 \\
\hline $\begin{array}{l}\text { Columbian (ee) } \\
\text { Corak Bulu }\end{array}$ & 10 & 50,00 & 43 & 34,13 & 2 & 10,00 & 25 & 19,23 & 0 & 0,00 & 5 & 25,00 \\
\hline Lurik (B-) Jantan & 3 & 15,00 & 44 & 34,92 & 11 & 55,00 & 25 & 19,23 & 3 & 5,77 & 2 & 10,00 \\
\hline Polos (bb) Jantan & 17 & 85,00 & 62 & 49,21 & 9 & 45,00 & 23 & 17,69 & 27 & 51,92 & 18 & 90,00 \\
\hline Lurik (B-) Betina & - & - & 3 & 2,38 & - & - & 40 & 30,77 & 5 & 9,62 & - & - \\
\hline $\begin{array}{l}\text { Polos (bb) Betina } \\
\text { Kerlip Bulu }\end{array}$ & - & - & 17 & 13,49 & - & - & 42 & 32,31 & 17 & 32,69 & - & - \\
\hline Perak (S-) Jantan & 15 & 75,00 & 73 & 57,94 & 12 & 60,00 & 30 & 28,08 & 13 & 25,00 & 15 & 75,00 \\
\hline Emas (ss) Jantan & 5 & 25,00 & 33 & 26,19 & 8 & 40,00 & 18 & 13,85 & 17 & 32,69 & 5 & 25,00 \\
\hline Perak (S-) Betina & - & - & 20 & 15,87 & - & - & 66 & 50,77 & 9 & 17,31 & - & - \\
\hline Emas (ss) Betina & - & - & 0 & 0,00 & - & - & 16 & 12,30 & 13 & 25,00 & - & - \\
\hline
\end{tabular}

Keterangan: $n=$ jumlah ayam

\section{Corak Bulu}

Berdasarkan hasil pengamatan diketahui ada dua corak bulu pada ayam yaitu corak bulu lurik/bar (B-) dan polos/non bar (bb). Berdasarkan hasil penelitian corak bulu terkait kelamin pada ayam Bagon, Bangkok, Birma, Kampung, Katai dan Magon disajikan pada Tabel 1. Hasil uji kebebasan menunjukkan bahwa adanya keterhubungan $\left(X^{2}>X_{0,05}^{2}\right)$ antara sifat corak bulu dengan keenam jenis ayam yang diamati. Corak bulu lurik banyak dijumpai pada ayam Birma jantan $(55 \%)$ dan corak bulu polos banyak dijumpai pada ayam Bagon jantan (85\%).

\section{Kerlip Bulu}

Berdasarkan hasil pengamatan kerlip bulu dapat dilihat dengan jelas bila bulu ayam tersinari oleh cahaya matahari dengan penampakan yang lebih jelas pada bulu leher. Kerlip bulu ayam terbagi 
dua yaitu perak (S-) dan emas (ss), kerlip bulu perak biasanya dijumpai pada ayam berwarna bulu merah, coklat, hitam dan putih, sedangkan kerlip bulu emas terdapat pada bulu berwarna kuning keemasan. Berdasarkan hasil penelitian kerlip bulu terkait kelamin pada ayam Bagon, Bangkok, Birma, Kampung, Katai dan Magon disajikan pada Tabel 1. Hasil uji kebebasan menunjukkan bahwa adanya keterhubungan $\left(X^{2}>X_{0,05}^{2}\right)$ antara sifat kerlip bulu dengan keenam jenis ayam yang diamati. Kerlip bulu lurik banyak dijumpai pada ayam Bagon dan Magon jantan masing-masing sebesar $75 \%$ dan kerlip bulu emas banyak dijumpai pada ayam Katai jantan $(32,69 \%)$.

\section{Warna Shank}

Warna shank (cakar) pada ayam Bagon, Bangkok, Birma, Kampung, Katai dan Magon disajikan pada Tabel 2. Hasil uji kebebasan menunjukkan bahwa adanya keterhubungan $\left(X^{2}>\right.$ $\left.X_{0,05}^{2}\right)$ antara sifat warna shank dengan keenam jenis ayam yang diamati. Warna shank terpaut kelamin, dengan warna putih/kuning banyak dijumpai pada ayam Bagon jantan (100\%) dan shank warna hitam/abu-abu banyak dijumpai pada ayam Kampung betina (36,15\%). Dari hasil penelitian menunjukkan bahwa beberapa warna shank yang berbeda ditemukan pada ayam dari kombinasi pigmen yang berbeda dilapisan atas dan bawah kulit. Hal ini sesuai dengan pernyataan Somes (1978) yang menyatakan bahwa warna shank merupakan penampilan dari adanya beberapa pigmen tertentu pada epidermis dan dermis, warna kuning pada shank dikarenakan adanya lemak atau pigmen lipokrom pada lapisan epidermis.

Tabel 2. Frekuensi fenotipe sifat kualitatif warna shank dan bentuk jengger ayam bagon, bangkok, birma, kampung, katai dan magon

\begin{tabular}{|c|c|c|c|c|c|c|c|c|c|c|c|c|c|}
\hline \multirow{3}{*}{ Sifat Kualitatif } & \multicolumn{12}{|c|}{ Frekuensi Fenotipe Pada Jenis Ayam } & \\
\hline & \multicolumn{3}{|c|}{$\begin{array}{l}\text { Bagon } \\
(\mathrm{n}=20)\end{array}$} & \multicolumn{2}{|c|}{$\begin{array}{l}\text { Bangkok } \\
(\mathrm{n}=126)\end{array}$} & \multicolumn{3}{|c|}{$\begin{array}{c}\text { Birma } \\
(\mathrm{n}=20)\end{array}$} & \multicolumn{2}{|c|}{$\begin{array}{l}\text { Kampung } \\
(\mathrm{n}=130)\end{array}$} & \multicolumn{2}{|r|}{$\begin{array}{l}\text { Katai } \\
(n=52)\end{array}$} & $\begin{array}{l}\text { Magon } \\
(\mathrm{n}=20)\end{array}$ \\
\hline & & $\mathrm{n}$ & $(\%)$ & $\mathrm{n}$ & $(\%)$ & $\mathrm{n}$ & $(\%)$ & & $\mathrm{n}$ & $(\%)$ & & $\mathrm{n} \quad(\%)$ & $\mathrm{n} \quad(\%)$ \\
\hline \multicolumn{14}{|l|}{ Warna Shank } \\
\hline Putih/kuning (Id-) & Jantan & 20 & 100,00 & 87 & 69,05 & 168 & 0,00 & & 25 & 19,23 & & 1332,69 & 1785,00 \\
\hline Hitam/abu (idid) $]$ & antan & 0 & 0,00 & 19 & 15,08 & 42 & 0,00 & & 23 & 17,70 & & 1725,00 & 315,00 \\
\hline Putih/kuning (Id-) & Betina & - & - & 12 & 9,52 & - & - & & 35 & 26,92 & & 1121,15 & $-\quad-$ \\
\hline $\begin{array}{l}\text { Hitam/abu (idid) } \\
\text { Bentuk Jengger }\end{array}$ & etina & - & - & 8 & 6,35 & - & - & & 47 & 36,15 & & 1121,15 & - \\
\hline Kapri (P-) & 20 & 100,00 & 112 & 88,89 & 16 & 80,0 & & 61 & & 5,92 & 0 & 0,00 & 20100,00 \\
\hline Tunggal (pp) & 0 & 0,00 & 14 & 11,11 & 4 & 20,0 & & 69 & &, 08 & 52 & 100,00 & $0 \quad 0,00$ \\
\hline
\end{tabular}

Keterangan: $n=$ jumlah ayam 


\section{Bentuk Jengger}

Bentuk jengger pada ayam Bagon, Bangkok, Birma, Kampung, Katai dan Magon disajikan pada Tabel 2. Hasil uji kebebasan menunjukkan bahwa adanya keterhubungan $\left(X^{2}>\right.$ $X_{0,05}^{2}$ antara sifat bentuk jengger dengan keenam jenis ayam yang diamati. Bentuk jengger kapri banyak dijumpai pada ayam Bagon dan Magon (100\%) dan bentuk jengger tunggal banyak dijumpai pada Katai (100\%). Dari pemaparan hasil diatas dapat dikatan bahwa kemurnian ayam Bagon, Magon dan Katai dapat ditentukan pada bentuk jengger yang muncul sebagai ciri khas tertentu yang dapat menjadi pembeda pada kedua jenis ayam ini, namun pada ayam Kampung hal ini sulit untuk di bandingkan dikarenakan tingkat variasi bentuk jengger yang tinggi sehingga sulit didefinisikan sebagai ayam yang memiliki ciri-ciri khas tertentu.

\section{Frekuensi Gen}

Frekuensi gen adalah salah satu parameter genetik yang mampu menggambarkan status genetik suatu populasi ternak. Keragaman genetik yang tinggi pada suatu populasi ternak merupakan modal dasar dalam melakukan seleksi. Jumlah ayam yang diamati 368 ekor diantaranya ayam Bagon 20 ekor, Bangkok 126 ekor (106 ekor jantan dan 20 ekor betina), Birma 20 ekor, Kampung 130 ekor (48 ekor jantan dan 82 ekor betina), Katai 52 ekor dan (30 ekor jantan dan 22 ekor betina), Magon 20 ekor. Berdasarkan pengamatan sifat kualitatif (warna bulu, pola bulu, corak bulu, kerlip bulu, warna shank dan bentuk jengger) pada beberapa populasi ayam piara, diperoleh bahwa frekuensi gen dari masing-masing ayam yang diamati disajikan pada Tabel 3 .

Tabel 3. Frekuensi gen autosomal dan sex-linked antar jenis ayam

\begin{tabular}{|c|c|c|c|c|c|c|c|c|c|}
\hline \multirow{2}{*}{ Sifat kualitatif } & \multirow{2}{*}{ tif Lokus } & \multirow{2}{*}{ Fenotipe } & \multirow{2}{*}{ Genotipe } & \multicolumn{6}{|c|}{ Frekuensi gen } \\
\hline & & & & $\begin{array}{l}\text { Bagon } \\
(n=20)\end{array}$ & $\begin{array}{l}\text { Bangkok } \\
(n=126)\end{array}$ & $\begin{array}{c}\text { Birma } \\
(n=20)\end{array}$ & $\begin{array}{l}\text { Kampung } \\
(\mathrm{n}=130)\end{array}$ & $\begin{array}{l}\text { Katai } \\
(n=52)\end{array}$ & $\begin{array}{l}\text { Magon } \\
(n=20)\end{array}$ \\
\hline \multirow[t]{2}{*}{ Warna Bulu } & $\mathrm{I}>\mathrm{i}$ & Putih & I- & 0,0000 & 0,0080 & 0,0253 & 0,0077 & 0,0293 & 0,0000 \\
\hline & & Berwarna & ii & 1,0000 & 0,9920 & 0,9747 & 0,9923 & 0,9707 & 1,0000 \\
\hline \multirow[t]{3}{*}{ Pola Bulu } & $E>e+>e$ & Hitam & E- & 0,1340 & 0,1439 & 0,3292 & 0,3039 & 0,0293 & 0,1056 \\
\hline & & Tipe Liar & $\mathrm{e}+$ & 0,1589 & 0,2719 & 0,3546 & 0,2576 & 0,9707 & 0,3944 \\
\hline & & Columbian & ee & 0,7071 & 0,5842 & 0,3162 & 0,4385 & 0,0000 & 0,5000 \\
\hline Corak & $\mathrm{B}>\mathrm{b}$ & Lurik & B- & 0,0781 & 0,2278 & 0,3292 & 0,3898 & 0,0976 & 0,0513 \\
\hline Bulu & (Sex-linked) & Polos & $\mathrm{bb}$ & 0,9219 & 0,7722 & 0,6708 & 0,6102 & 0,9024 & 0,9487 \\
\hline Kerlip & $S>S$ & Perak & S- & 0,5000 & 0,4893 & 0,3676 & 0,5798 & 0,2907 & 0,5000 \\
\hline Bulu & (Sex-linked) & Emas & ss & 0,5000 & 0,5197 & 0,6324 & 0,4202 & 0,7093 & 0,5000 \\
\hline Warna & Id $>$ id & Putih/kunin & ng Id- & 1,0000 & 0,5778 & 0,5528 & 0,3617 & 0,3842 & 0,6127 \\
\hline Shank & (Sex-linked) & Hitam/abu- & -abu idid & 0,0000 & 0,4222 & 0,4472 & 0,6383 & 0,6158 & 0,3873 \\
\hline Bentuk & $\mathrm{P}>\mathrm{p}$ & Kapri & $\mathrm{P}-$ & 1,0000 & 0,6667 & 0,5528 & 0,2714 & 0,0000 & 1,0000 \\
\hline Jengger & & Tunggal & $\mathrm{pp}$ & 0,0000 & 0,3333 & 0,4472 & 0,7286 & 1,0000 & 0,0000 \\
\hline
\end{tabular}

Keterangan: $n=$ jumlah ayam 
Berdasarkan data di atas, terlihat bahwa frekuensi gen dominan muncul sangat bervariasi pada setiap jenis ayam yang diamati. Berdasarkan frekuensi gen pengontrol tertinggi dapat dijelaskan bahwa ayam Bagon dan ayam Birma lebih menunjukkan ciri-ciri genotipe dan fenotipe kualitatif warna bulu, pola bulu, corak bulu, kerlip bulu, warna shank dan bentuk jengger yang relatif lebih seragam (ii e+ bb ss $\mathrm{Id}_{-} \mathrm{P}_{-}$) dibandingkan ayam lainnya. Sedangkan ayam Kampung menunjukkan tingkat keragaman genotipe dan fenotipe sifat kualitatif yang tinggi (ii ee bb S_ idid pp). Hal ini menandakan bahwa pada ayam Kampung perkawinan masih terjadi secara acak atau proses domestikasinya telah berlangsung cukup lama namun seleksi pada sifat kualitatif warna bulu, pola bulu, corak bulu, kerlip bulu, warna shank dan bentuk jengger masih belum dilakukan. Hal ini sesuai dengan pernyataan Sartika dan Iskandar (2007) yang menyatakan bahwa ayam kampung didefenisikan sebagai ayam yang tidak mempunyai ciri-ciri khas tertentu, dengan kata lain penampilan fenotipenya masih sangat beragam.

\section{Perbandingan Morfometrik Antar Jenis Ayam}

Rataan dan simpangan baku ukuran tubuh antar jenis ayam ditampilkan pada tabel 4. Jumlah keseluruhan ayam yang diamati adalah 368 ekor, diantaranya ayam Kampung 130 ekor, Bangkok 126 ekor, Birma 20 ekor, Magon (Birma x Shaigon) 20 ekor, Bagon (Bangkok x Shaigon) 20 ekor dan Katai 52 ekor. Perbedaan dari keenam jenis ayam tersebut dapat pada Tabel 5. Hasil penelitian menunjukkan bahwa jenis ayam Katai memiliki ukuran tubuh yang paling kecil dibandingkan dengan ayam Bangkok, Bagon, Birma, Shaigon dan Kampung kecuali pada panjang jengger $(45,38 \pm 19,634 \mathrm{~mm})$, sedangkan ukuran tubuh paling besar dimiliki oleh ayam Birma yaitu pada peubah panjang femur $(128,03 \pm 11,378 \mathrm{~mm})$, panjang tibia $(148,61 \pm 5,778 \mathrm{~mm})$, panjang maxilla $(38,30 \pm 1,333 \mathrm{~mm})$ dan panjang jari ketiga $(75,29 \pm 3,446$ $\mathrm{mm})$. Hasil perbandingan rataan yang diperoleh dari kedua jenis ayam tersebut menunjukkan bahwa adanya perbedaan kapasitas penyusun kerangka tubuh yang sebagian besar dipengaruhi faktor genetik dan faktor lingkungan walau kemungkinannya sangat kecil terjadi, sehingga dapat ditarik kesimpulan semakin besar ukuran kerangka tubuh suatu individu maka ukurannya tubuh juga akan besar. Menurut Soeparno (1992) yang menyatakan perbedaan komposisi tubuh diantara bangsa ternak terutama disebabkan oleh perbedaan ukuran tubuh dewasa. Faktor lingkungan dan genetik mempunyai hubungan yang erat untuk mengekspresikan kapasitas 
genetik individu secara sempurna diperlukan kondisi lingkungan yang ideal. Koefisien keragaman pada antar jenis ayam ditampilkan pada Tabel 4.

Tabel 4. Rataan, simpangan baku, koefisien keragaman peubah antar jenis ayam Jenis Ayam

\begin{tabular}{ccccccc} 
Peubah & Bagon & Bangkok & Birma & Kampung & Katai & Magon \\
\hline Panjang Femur & $122,22^{\mathrm{B}} \pm 4,600$ & $127,13^{\mathrm{AB}} \pm 10,579$ & $128,03^{\mathrm{A}} \pm 11,378$ & $98,47^{\mathrm{C}} \pm 10,688$ & $71,24^{\mathrm{D}} \pm 9,646$ & $124,22^{\mathrm{AB}} \pm 5,666$ \\
KK(\%) & 3,76 & 8,32 & 8,86 & 10,85 & 13,54 & 4,57 \\
Panjang Tibia & $147,41^{\mathrm{A}} \pm 3,086$ & $144,78^{\mathrm{A}} \pm 10,154$ & $148,61^{\mathrm{A}} \pm 5,778$ & $134,03^{\mathrm{B}} \pm 12,530$ & $91,75^{\mathrm{C}} \pm 16,910$ & $147,47^{\mathrm{A}} \pm 5,207$ \\
KK(\%) & 2,09 & 7,01 & 3,88 & 9,34 & 1,84 & 4,56 \\
Panjang Shank & $111,76^{\mathrm{A}} \pm 9,657$ & $106,59^{\mathrm{A}} \pm 10,853$ & $111,40^{\mathrm{A}} \pm 8,222$ & $87,79^{\mathrm{B}} \pm 11,761$ & $58,37^{\mathrm{C}} \pm 10,512$ & $108,96^{\mathrm{A}} \pm 7,563$ \\
KK(\%) & 8,64 & 10,18 & 7,38 & 13,39 & 18,00 & 6,94 \\
Lingkar Shank & $69,97^{\mathrm{A}} \pm 4,312$ & $68,80^{\mathrm{A}} \pm 5,723$ & $69,00^{\mathrm{A}} \pm 4,702$ & $50,52^{\mathrm{B}} \pm 5,384$ & $47,42^{\mathrm{C}} \pm 5,509$ & $69,03^{\mathrm{A}} \pm 4,863$ \\
KK(\%) & 6,16 & 8,31 & 6,81 & 10,65 & 11,61 & 7,04 \\
Panjang Sayap & $278,26^{\mathrm{A}} \pm 13,939$ & $236,09^{\mathrm{C}} \pm 17,479$ & $266,22^{\mathrm{B}} \pm 19,702$ & $227,96^{\mathrm{C}} \pm 17,295$ & $155,98^{\mathrm{D}} \pm 19,364$ & $272,41^{\mathrm{AB}} \pm 16,220$ \\
KK(\%) & 5,00 & 7,40 & 7,40 & 7,58 & 12,41 & 5,95 \\
Panjang Maxilla & $37,14^{\mathrm{A}} \pm 2,698$ & $36,99^{\mathrm{B}} \pm 2,416$ & $38,30^{\mathrm{A}} \pm 1,333$ & $32,36^{\mathrm{C}} \pm 2,265$ & $25,27^{\mathrm{D}} \pm 3,152$ & $37,86^{\mathrm{A}} \pm 2,456$ \\
KK(\%) & 7,26 & 6,53 & 3,48 & 6,99 & 12,47 & 6,48 \\
Panjang Jari Ketiga & $74,38^{\mathrm{A}} \pm 3,586$ & $70,97^{\mathrm{B}} \pm 7,565$ & $75,29^{\mathrm{A}} \pm 3,446$ & $58,83^{\mathrm{C}} \pm 5,627$ & $42,75^{\mathrm{D}} \pm 6,912$ & $72,68^{\mathrm{A}} \pm 4,450$ \\
KK(\%) & 4,82 & 10,65 & 4,57 & 9,56 & 16,56 & 6,12 \\
Tinggi Jengger & $31,09^{\mathrm{D}} \pm 10,088$ & $30,16^{\mathrm{B}} \pm 12,448$ & $44,95^{\mathrm{C}} \pm 14,285$ & $36,11^{\mathrm{B}} \pm 18,940$ & $45,38^{\mathrm{A}} \pm 19,634$ & $34,96^{\mathrm{D}} \pm 10,303$ \\
KK(\%) & 32,44 & 41,27 & 31,77 & 52,45 & 43,26 & 29,47 \\
\hline Ket & & &
\end{tabular}

Ket: Huruf superskrip yang berbeda pada peubah yang sama menyatakan berbeda nyata $(\mathrm{P}>0,05$.)

\section{Peubah Pembeda Antar Jenis Ayam}

Total struktur kanonik antar jenis ayam yang merupakan analisis diskriminan ditampilkan pada Tabel 5. Analisis diskriminan digunakan untuk menentukan beberapa ukuran fenotipik dari peubah yang memiliki pengaruh kuat terhadap terjadinya pembeda pengelompokan ternak. Analisis variat kanonikal menurut Wiley (1981) digunakan untuk mendapatkan kombinasi karakter yang membedakan secara keseluruhan dan dapat digunakan untuk menggambarkan plot skor guna membandingkan didalam dan diantara variabilitas populasi (kelompok ayam) pada dimensi yang kecil. Pada analisis diskriminan, total struktur kanonikal KAN1 dapat diindikasikan sebagai bagian dari ukuran (size) hewan yang diteliti (vektor ukuran) dan KAN2 dapat dindikasi dan komponen kedua yang merupakan indikasi dari bentuk (shape) hewan yang diteliti (vektor bentuk).

Menurut Nishida et al. (1982), bentuk (shape) tubuh ayam asli Indonesia dipengaruhi oleh tinggi jengger, panjang sayap, panjang femur, dan panjang tibia. Lebih lanjut dijelaskan 
bahwa ukuran (size) tubuh ayam dicirikan oleh panjang sayap, panjang femur, panjang tibia, panjang tarsometatarsus dan tinggi jengger. Berdasarkan hasil analisis dapat diketahui peubahpeubah ukuran tubuh yang memberikan pengaruh yang kuat dalam membedakan antar jenis ayam adalah panjang femur (0,928976), panjang tibia $(0,834304)$, panjang shank $(0,887502)$, lingkar shank $(0,843363)$, panjang sayap $(0,834857)$, panjang maxilla $(0,900950)$ dan panjang jari ketiga $(0,895067)$ pada KAN1, panjang tibia $(0,297752)$ dan panjang sayap $(0,421491)$ pada KAN2. Pendugaan tersebut didasari dari tingginya nilai kanonikal dari peubah panjang femur, panjang tibia, panjang shank, lingkar shank, panjang sayap, panjang maxilla dan panjang jari ketiga.

Tabel 5. Total struktur kanonikal antar jenis ayam

\begin{tabular}{lcc}
\hline Variabel Peubah & KAN1 & KAN2 \\
\hline Panjang Femur & 0.928976 & -0.104593 \\
Panjang Tibia & 0.834304 & 0.297752 \\
Panjang Shank & 0.887502 & 0.067942 \\
Lingkar Shank & 0.843363 & -0.397024 \\
Panjang Sayap & 0.834857 & 0.421491 \\
Panjang Maxilla & 0.900950 & 0.056896 \\
Panjang Jari Ketiga & 0.895067 & 0.021128 \\
Panjang Jengger & -0.257346 & -0.010807 \\
\hline
\end{tabular}

\section{Nilai Kesamaan dan Campuran Antar Jenis Ayam}

Pendugaan nilai kesamaan fenotifik antar jenis ayam dengan analisis diskriminan, persentase nilai kesamaan dan campurannya ditampilkan pada Tabel 6. Nilai tersebut menjelaskan proporsi nilai campuran yang mempengaruhi kesamaan antar jenis ayam dengan jenis lainnya berdasarkan ukuran morfometrik.

Tabel 6. Persentase nilai kesamaan dan campuran antar jenis ayam

\begin{tabular}{lccccrrc}
\hline Jenis Ayam & Bagon & Bangkok & Birma & Kampung & Katai & Magon & Total \\
\hline Bagon & 75,00 & 5,00 & 5,00 & 0,00 & 0,00 & 15,00 & 100,00 \\
Bangkok & 3,17 & 84,13 & 6,35 & 0,79 & 0,00 & 5,56 & 100,00 \\
Birma & 10,00 & 30,00 & 40,00 & 0,00 & 0,00 & 20,00 & 100,00 \\
Kampung & 0,00 & 0,77 & 0,77 & 98,46 & 0,00 & 0,00 & 100,00 \\
Katai & 0,00 & 0,00 & 0,00 & 0,00 & 100,00 & 0,00 & 100,00 \\
Magon & 20,00 & 10,00 & 5,00 & 0,00 & 0,00 & 65,00 & 100,00 \\
\hline
\end{tabular}

Kesamaan ukuran morfometrik antar jenis ayam dari tinggi ke yang rendah berturut-turut adalah ayam Katai (100\%), Kampung (98,46\%), Bangkok (84,13\%), Bagon (75,00\%), Magon $(65,00 \%)$ dan Birma (40,00\%). Hasil analisis menunjukkan ayam Katai tidak ada tercampur dengan jenis ayam lain (100\%). Hal ini menunjukkan sangat tingginya kemurniaan ayam Katai. 
Fenotifik paling rendah ialah ayam Birma (40,00\%) yang dipengaruhi dua jenis ayam lainnya, yang lebih dominan mempengaruhi adalah jenis ayam Bangkok (30,00\%). Hal ini menunjukkan kemurnian ayam Birma sangat rendah dan banyak dipengaruhi oleh ayam Bangkok. Dari keenam jenis ayam terdapat ayam Magon dan Bagon yang memiliki kesamaan fenotifik tertinggi yaitu sebesar 20,00\%. Tingginya kesamaan ayam Magon dan Bagon dapat dipengaruhi oleh sistem tata laksana perkandangan dan faktor genetik seperti pernyataan Noor (1995) yang menyatakan kesamaan atau keragaman fenotifik disebabkan interaksi genetik dan lingkungan. Kesamaaanfenotifik tertinggi terdapat pada ayam kampung sebesar $98,46 \%$, mendapat pengaruh dari ayam Bangkok 0,77\% dan Birman 0,77\%. Hal ini menunjukkan ayam kampung lebih murni dan sedikit tercampur dengan darah kedua jenis ayam lainnya.

\section{Peta Penyebaran Antar Jenis Ayam}

Peta penyebaran antar jenis ayam berdasarkan ukuran-ukuran tubuh yang menggambarkan pemisahan antar jenis ayam ditampilkan pada Gambar 2. Plot data hasil analisis diskriminan dapat digunakan untuk menggambarkan pemisahan maksimum yang mungkin terjadi antara kelompok yang diuji. Hasil analisis pada Gambar 2 memperlihatkan ayam Kampung (B) dominan berkelompok pada sebelah kiri atas aksis Y memperlihatkan penampilan fenitipik yang berbeda dibandingkan jenis ayam lainnya walau terdapat sedikit penyebaran ke sebelah kiri bawah aksis Y dan sebelah kanan atas aksis Y. Ayam Katai (C) memperlihatkan penampilan pengelompokan fenotipik yang sangat jauh berbeda disebelah kiri axis $\mathrm{Y}$ dibawah kiri axis $\mathrm{X}$, tergambarkan terpisah dari kelompok ayam lainnya. Gambaran sebaran ini mencirikan bahwa ayam katai memiliki ukuran fenotipik yang sangat jauh berbeda secara relative dengan jenis ayam lainnya dan jarak yang jauh terpisah. Kemudian ayam Bangkok (A) mengelompok lebih dominan kesebelah kanan bawah aksis $\mathrm{X}$ yang ikut terapatan kerumunan yang saling beririsan antara ayam Birma (D), Magon (E) dan Bagon (F). Kerumunan kelompok ayam Magon dan Bagon beririsan dengan Ayam Bangkok dan Birma, hal ini terjadi karena ayam Bangkok dan Birma merupakan tetua dari ayam Magon dan Bagon sehingga Ayam Magon dan Bagon akan beririsan dengan keduanya. 


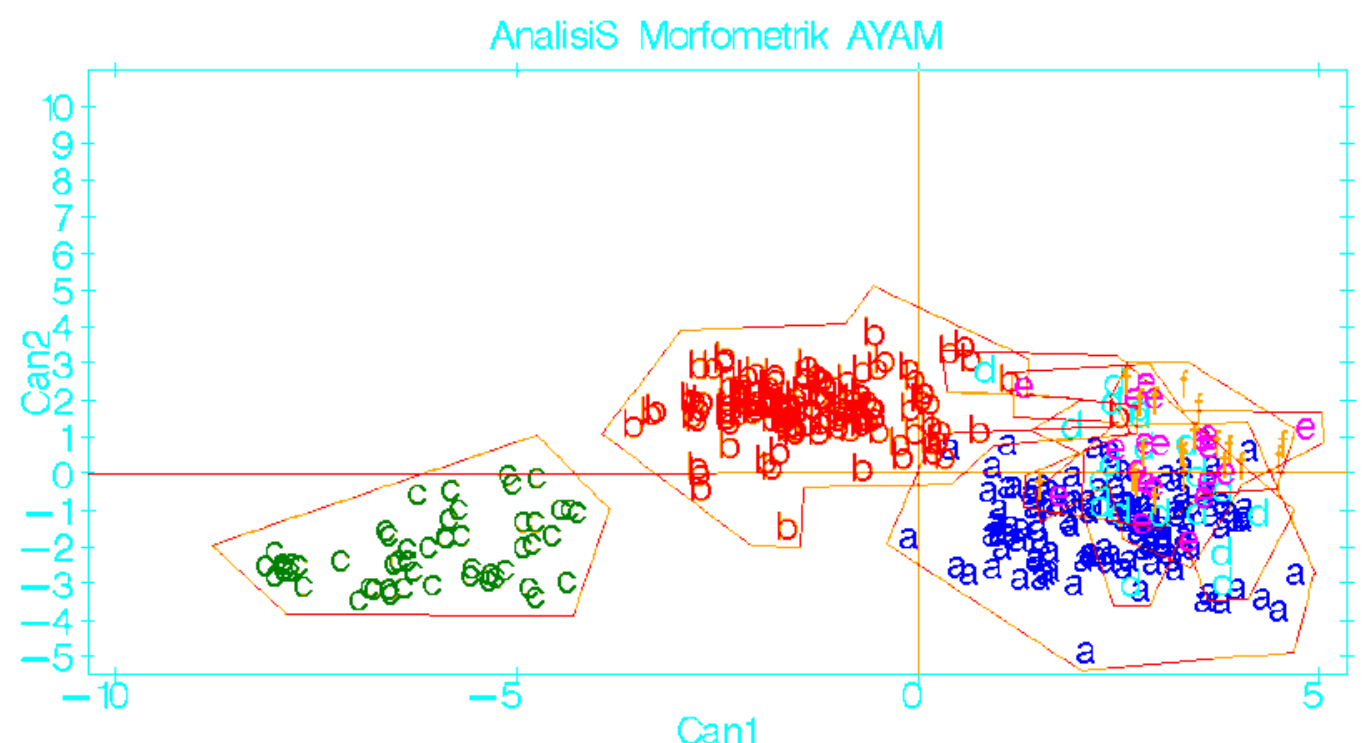

Gambar 2. Peta Penyebaran Antar Jenis Ayam

Keterangan : Bangkok (a), Kampung (b), Katai (c), Birma (d), Magon (e), Bagon (f).

Secara keseluruhan antar jenis ayam berkrumun di axis X dengan banyaknya irisan antar klompok krumunan (Bangkok, Birma, Magon dan Bagon), hal ini mengindikasikan tingkat persilangan yang tinggi dan berada pada populasi dan lingkungan yang sama baik pada pakan dan menejemen pemeliharaan yang dapat mempengaruhi ukuran tubuh ayam-ayam tersebut.

\section{Jarak Genetik dan Dendogram antar Jenis Ayam}

Tampilan nilai matrik jarak genetik antar masing-masing ayam dapat dilihat pada Tabel 7, nilai tersebut diperoleh dari hasil analisis diskriminan yang menghasilkan kuadrat jarak antar jenis ayam yang diamati.

Tabel 7. Matriks jarak genetik antar jenis ayam.

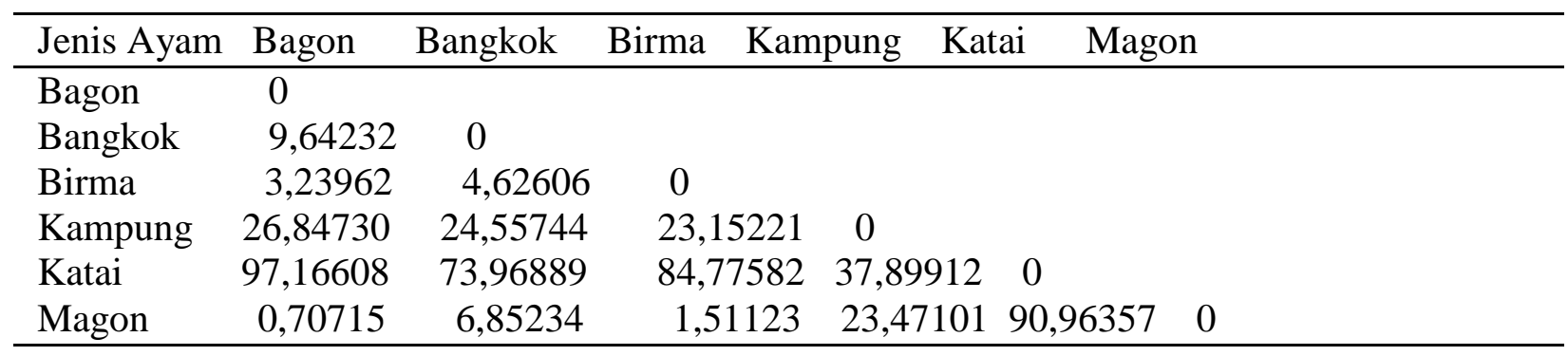

Penentuan jarak genetik berdasarkan karakteristik ukuran tubuh menunjukkan jarak terdekat antara ayam Bagon dengan ayam Magon yaitu sebesar 0,70715. Sedangkan jarak 
genetik terjauh dijumpai antara ayam Katai dengan ayam Bagon sebesar 97,16608 dan ayam Katai dengan ayam Bagon sebesar 90,96357. Untuk melihat gambaran kedekatan dan gambaran terjauh antar jenis ayam diatas dapadilihat pada dendogram jarak genetik.

Dendogram yang ditampilkan pada gambar 3 diperoleh dari metriks jarak genetik pada Tabel 7. Dendogram menunjukkan ayam Bagon dengan ayam Magon memiliki hubungan kekerabatan yang dekat. Dapat disimpulkan bila terjadi persilangan antara ayam Bagon dan Magon tidak akan memberikan perkembangan kuantitatif yang signifikan, hal ini dimungkinkan karena kecilnya peluang terjadinya heterosis (pengukuran kuantitatif rataan keunggulan anak terhadap rataan tetuanya) pada hasil persilangan antara keduanya. Jenis ayam yang memiliki hubungan kekerabatan terjauh adalah ayam Kampung dan ayam Katai, halal ini menunjukkan kemungkinan terjadinya peningkatan heterosis pada kedua ayam tersebut.

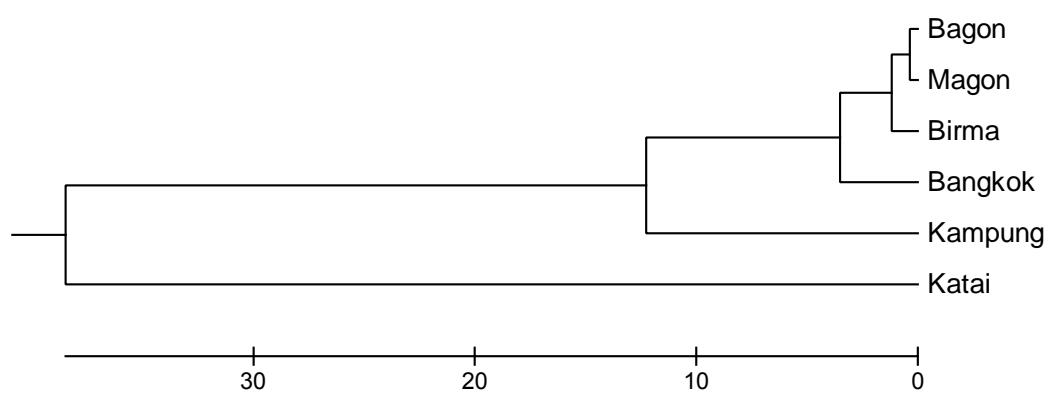

Gambar 3. Dendogram antar jenis ayam Bagon, Magon, Birma, Bangkok, Kampung dan Katai

\section{KESIMPULAN}

Hasil penelitian uji kebebasan menunjukkan bahwa adanya keterhubungan yang sangat nyata $\left(X^{2}>X_{0,05}^{2}\right)$ antara sifat pola bulu, corak bulu, kerlip bulu, warna shank dan bentuk jengger, tetapi tidak adanya keterhubungan $\left(X^{2}<X^{2}{ }_{0,05}\right)$ antara warna bulu dan jenis ayam yang diamati. Penciri yang membedakan antar jenis ayam ini adalah panjang femur, panjang tibia, panjang shank, lingkar shank, panjang sayap, panjang maxilla dan panjang jari ketiga.

Tingkat kemurnian antar jenis ayam adalah Katai 100\%, Kampung 98,46\%, Bangkok 84,13\%, Bagon 75,00\%, Magon 65,00\% dan Birma 40,00\%. Ayam Bagon dan ayam Magon memiliki hubungan kekerabatan yang dekat, sebaliknya ayam Kampung dan ayam Katai memiliki hubungan kekerabatan yang jauh. 


\section{DAFTAR PUSTAKA}

North OM., Bell DD. 1990. Commercial Chiken Production Manual. $4^{\text {th }}$ Ed. Westport, Conecticut: The Avian Publishing Company, Inc.

Nishida, T., K. Nozawa, K. Kondo, S.S. Mansjoer and H. Martojo. 1980. Morphological and genetical studies on the Indonesian native fowl. The Origin and Phylogeny of Indonesian Native Livestock. The Research Group of Overseas Scientific Survey. Hal : 47-70.

Nishida, T., K. Nozawa, Y. Hayashi, T. Hashiguchi and S.S. Mansjoer. 1982. Bodymeasurement and analysis of external genetic characters of Indonesian nativefowl. The Origin and Phylogeny of Indonesian Native Livestock. TheResearch Group of Overseas Scientific Survey.

Mulliono, R. H dan R. B. Panestu. 1996. Analisis statistik ukuran-ukuran tubuh dan analisis karakter-karakter genetik eksternal pada ayam Kampung, Pelung dan Kedu. Seminar Hasil Penelitian Institut Pertanian Bogor.

Mansjoer I, Mansjoer SS, Sayuthi D. 1989. Studi banding sifat-sifat biologis ayam Kampung, ayam Pelung dan ayam Bangkok [laporan Penelitian]. Bogor: Institut Pertanian Bogor

Noor, R. R. 1995. Genetika Ternak. Penebar Swadaya. Jakarta.

Nishida T, Hayashi Y, Hashiguchi T, Mansjoer SS. 1982. Distribution and identification of jungle fowl in Indonesia. The Origin and Phylogeny of Indonesian Native Livestock. Part III: 85-95. Report by The Research Group of Overseas Scientific Survey.

Somes, N. 1978. Molecular Evolutionary Genetics. Columbia University Press, New York.

Somes RG 1988. International Registery of Poultry Genetic Stocks. Bulletin Document No. 476. Storrs Agricultural Experiment Station, The University of Connecticut 06268

Sartika T. dan S. Iskandar. 2007. Mengenal Plasma Nutfah Ayam Indonesia dan Pemanfaatannya. Buku. Edisi pertama. Balai Penelitian Ternak, Bogor.

Syahrul, 2013. Hasil Wawancara di Penangkaran Ayam Hias Aduan di Martubung, Kecamatan Medan Labuhan.

Soeparno. 1992. Ilmu dan Teknologi Daging. Gadjah Mada University Press. Yogyakarta.

Wiley, E. O. 1981. Phylogenetics: The Theory and Practice of Phylogenetic Systematics. Jhon Wiley \& Sons Inc., Canada.

Warwick, E.J., J.M. Astuti dan W. Hardjosubroto. 1995. Pemuliaan Ternak. Edisi kelima. Gadjah Mada University Press, Yogyakarta. 
Jurnal Peternakan Integratif Vol. 3 No. 2 : 167-189 